\title{
REVITALIZATION OF THE 1970S WITHIN THE ‘OLD TOWN' IN KRAKÓW
}

\author{
Paweł ŻWIREK ${ }^{1}$, Jakub FISZER ${ }^{2}$ \\ ${ }^{1}$ Cracow University of Technology Tadeusz Kościuszko \\ Faculty of Civil Ingineering, Kraków, Poland \\ ${ }^{2}$ AKE Studio Spółka z o.o., Kraków, Poland
}

\begin{abstract}
The paper presents selected issues in the revitalization of the façades of buildings located in the historic 'Old Town' part of the city of Kraków. The subjects of the revitalization were the façades of an office building and a multi-level garage, both built in the 1970s in the administrative district of the 'Old Town' in Krakow. The criteria that guided the project heads in the choice of technology and technical solutions used in the revitalization project are also presented. The paper discusses the problems associated with the implementation of a new aluminium façade on the exterior walls, which were characterized by very large inaccuracies, significantly exceeding tolerance values.
\end{abstract}

Keywords: office building, revitalization, aluminium, perforation, ventilated façade, expanded metal

\section{INTRODUCTION}

The subject of the revitalization project was a building complex consisting of the 'Prozam' office building (Fig. 1b, c) and a two-level garage with a ramped entrance (Fig. 1d), which was originally designed for the Provincial Committee of the Communist Party in Krakow. The design dates from 1972. The buildings are located in a historic part of Kraków known as the 'Old Town', on Smolensk

\footnotetext{
${ }^{1}$ Contact the author: Cracow University of Technology Tadeusz Kościuszko, Faculty of Civil Ingineering, Warszawska st 24, 31-155 Kraków, Poland, e-mail: pzwi@ pk.edu.pl

2 Corresponding author: AKE Studio Spółka z o.o., Mrozowa st 3, 31-752 Kraków, e-mail: ake@akestudio.com.pl
} 
street in what is now the administrative district (Fig. 1a), within the conservator's Protected Zone.

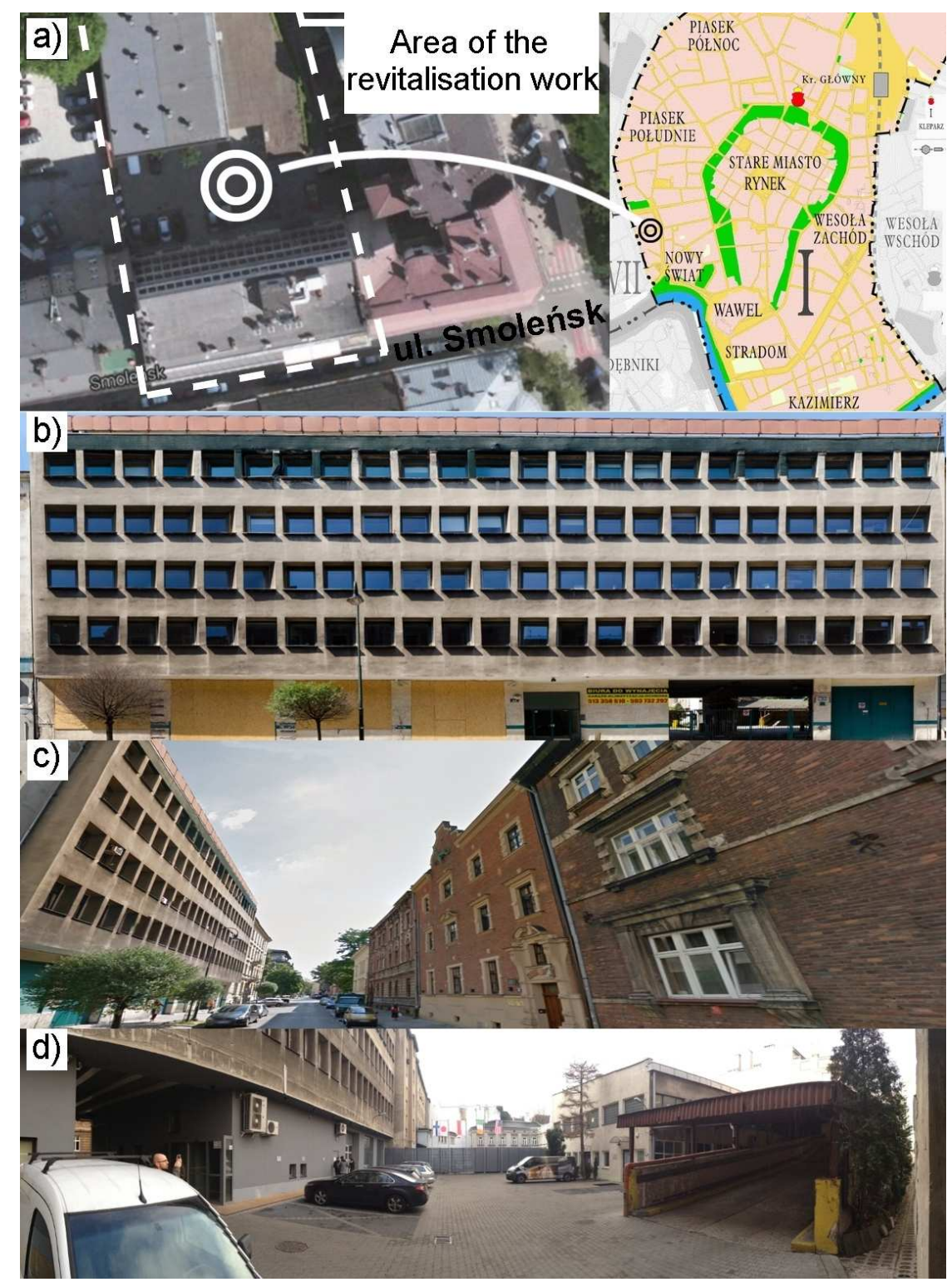

Fig. 1. a) Area of the revitalization work, b), c) The façade of the office building from Smoleńsk street, d) View of the courtyard, with a two-storey garage and ramped driveway 
The office building stands directly adjacent to several historic buildings, including two tenements built acc. to the design of the most highly noted Polish designer of the late 19th and early 20th century, Theodore Talowski [2]. The building and the garage date from the 1970s, and were characterized by a low standard of finishing and very low technical accuracy (Fig. 2a). The paper will present selected issues in the revitalization of façade, during which lightweight solid and perforated metal cladding was attached.

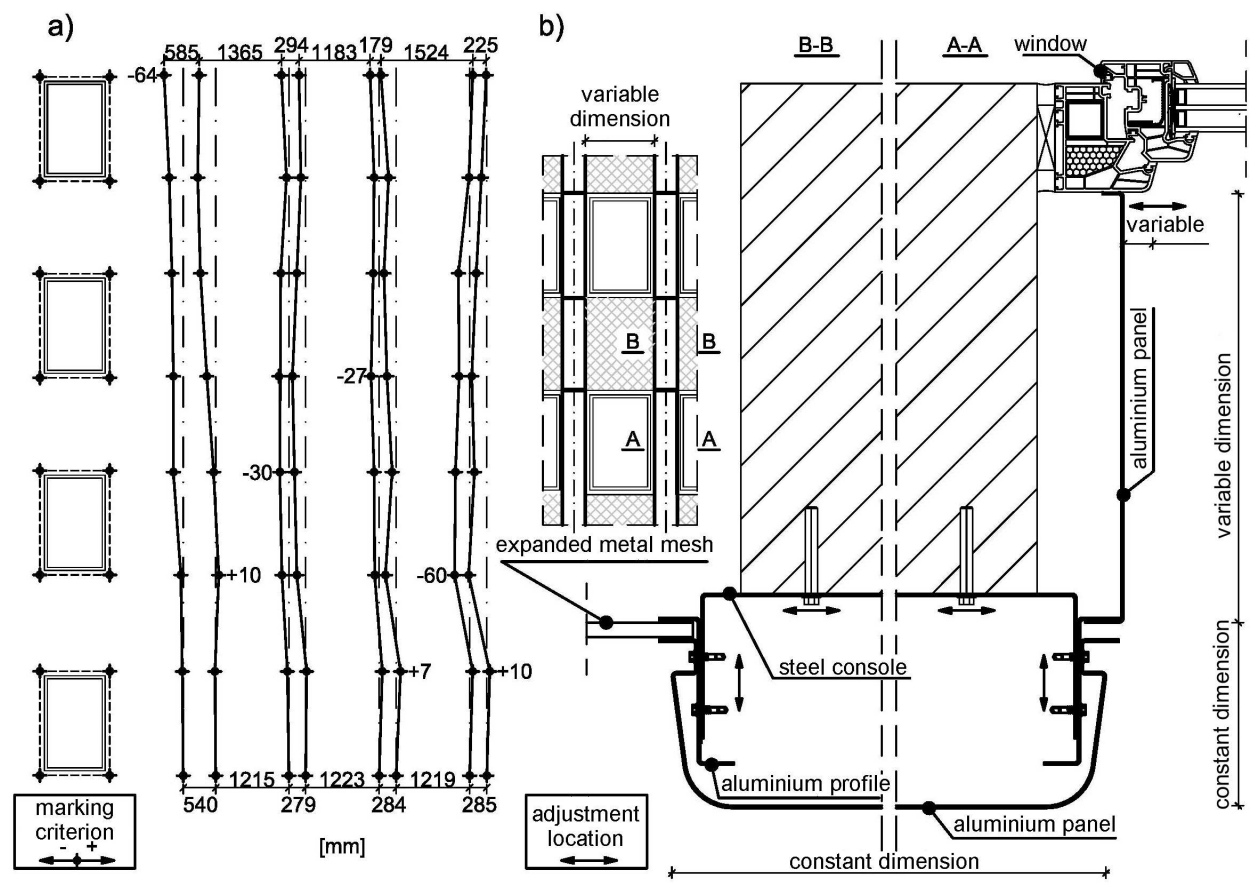

Fig. 2. a) Inventory of window positions in the parallel plane to Smoleńsk street (for the first three rows of windows on the left side) b) Wall detail

\section{REVITALIZATION OF THE OFFICE BUILDING'S FAÇADE}

\subsection{Condition before revitalization}

The 'Prozam' office building (Fig.1b, c) is a 6-storey building (with a lift shaft) and a total of $25.20 \mathrm{~m}$ height, $14.24 \mathrm{~m}$ width and $35.10 \mathrm{~m}$ length. The main supporting elements of the office building are monolithic reinforced concrete columns, beams and ceilings. The outer walls are made of PGS-07 class I cellular concrete buildings. The technical condition of the exterior walls before revitalization was generally good, except for parts of the walls on the highest 
floors, where damage to the flat roof's waterproofing had resulted in significant deterioration of the walls. Parts of the inter-window pillars were in such bad condition that they required complete reconstruction.

The specific architecture of the existing façade has very deep window cavities (Fig. 1b, c), resulting in the use of thick walls (tens of centimetres), which were made of cellular concrete that is characterized by low thermal conductivity. As a result, there was no need to perform additional thermal modernisation of the from the Smoleńsk street wall to adjust its parameters to modern regulations on thermal insulation baffles [5].

Before execution of the regeneration project, a preliminary inventory of the façade's existing geometric wall was carried out. Fig. 2a shows examples of horizontal measurements on the parallel plane to Smoleńsk street, and displacement of the corners of the window cavities from the lower corners of the first floor. Fig. 2a shows the inventory results for a portion of the wall on which the largest displacement values were present. The inventory results indicated very low precision of workmanship, with deviations considerably exceeding the tolerances specified by the standards of that time [4]. The widths of the window cavities varied from $1,215 \mathrm{~mm}$ to $1,524 \mathrm{~mm}$; the width of the inter-window pillars from $179 \mathrm{~mm}$ to $285 \mathrm{~mm}$, and the deviation from the vertical position of the interwindow pillars located at successive levels was up to $60 \mathrm{~mm}$. Similar displacement values from the vertical were also obtained for measurements along the perpendicular plane to Smoleńsk street.

\subsection{Choice of materials}

Analysing the technologies used for revitalization of the façade, the following factors were taken into consideration:

- The location of premises within the conservator's protection zone,

- Low strength parameters (in terms of anchors' bearing capacity) of the cellular concrete substrate,

- Large deviations of the existing walls on the vertical plane,

- The wide range of variation in dimensions,

- Lack of need to provide thermoinsulation.

The use of light wet technology had to be rejected because of the location of the building within the conservator's protection zone. In addition, the use of light wet technology would be extremely complicated due to the significant inaccuracies in the existing wall and resulting need to use a levering layer as variable-thickness thermoinsulation on each section of wall.

Analysis of the anchoring systems pointed to their low load capacity in the substrate of the cellular concrete [3], which was confirmed by later tests. 
Characteristic and computational grab strength of the anchors was determined based on grab tests, carried out at the site in accordance with the guidelines set out in [3]. As a result of the low load capacity of the anchors, the possibility of using heavy stone, ceramic or glass cladding was rejected, which could have naturally visually referenced the façade of the adjacent buildings (Fig. 1c).

Therefore, lightweight cladding made of sheet aluminium and composite panels (e.g. Alucobond [1], etc) was selected. The choice of aluminium was arrived at as it provides greater possibility for forming and perforating (including the availability of expanded metal mesh), and the availability of a virtually unlimited range of colours in powder coating technology. Flexible AW-1050A alloyed aluminium was used, which has good susceptibility to bending and cold bending, and is highly resistant to atmospheric corrosion.

The concept for the revitalization took in the use of full, bright pilasters made of smooth powder-coated aluminium sheets. Dark, perforated strips of expanded metal mesh were placed between the pilasters (Fig. 3). The breaking up of the façade's plane with the introduction of strong vertical accents and materials of varying texture meant that the window cavities no longer dominated the façade. In addition, the elevation changes, depending on the angle at which an observer looks at the façade. When entering Smoleńsk street we can initially only see the bright pilasters, and as we move toward the building, the dark bands of expanded metal mesh begin to gradually emerge from behind them.

The windows had been replaced before the project, and so their location was matched to the position of the window cavities (Fig. 2a). For the project, nearly 1,500 window cavity geometry measurements were carried out. Due to the large number of inaccuracies in the existing façade, the vast majority of cladding elements required individual workshop documentation. Based on the inventory results, it was established that it would be possible to select the dimensions and position of the pilasters in such a way that they would run vertically along the entire height of the façade, and at the same time would not building the light of the window frames.

The window cavities panels were mounted perpendicular to the plane of the façade, which resulted in different window frame widths visible from the window cavity panel. Fig. 2b shows the solutions which were used to achieve the designed position of the individual elements of the new wall's housing even with the significant inaccuracies of the existing walls. Fig. 3 shows a view of the office building's façade after renovation. 


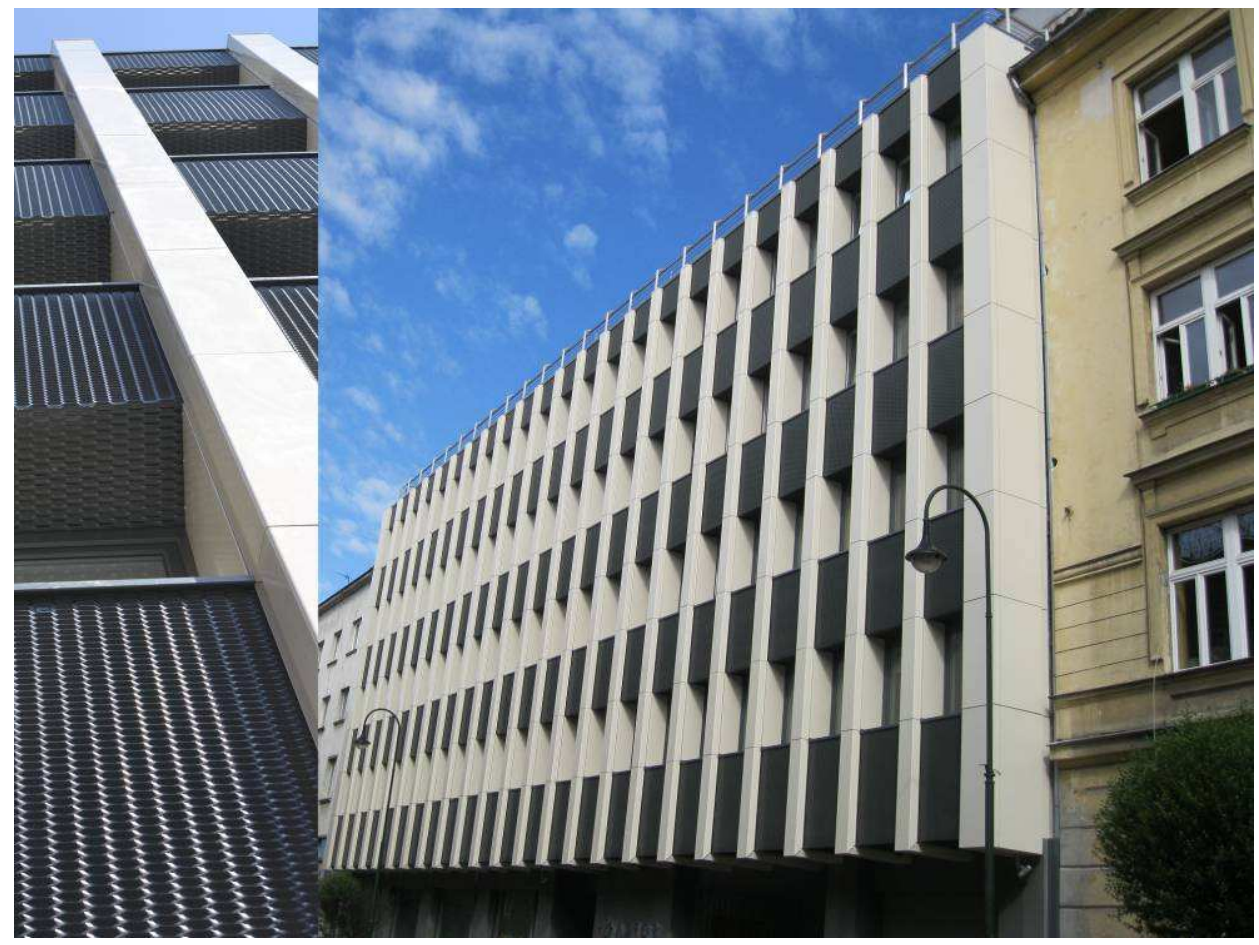

Fig. 3. Façade of the office building after revitalization

\section{REVITALIZATION OF THE GARAGE AND RAMPS' FAÇADE}

The off-street access road to the office building (Fig. 1b, d) leads to a courtyard behind the building, where training rooms are now located (originally, these were home to a car mechanic), along with a two-level garage with access ramps (Fig. 1d). The revitalization concept assumed, for example, optical masking of the existing offset between the building's structure and the ramp's roof (Fig.1c). This effect was achieved by making a false wall measuring about $3.5 \times 12.5 \mathrm{~m}$, enclosed by perforated aluminium panels. The perforations were made using numerically controlled turret punches, allowing for diversity in the perforation pattern and creating a spatial effect in the flat panels. The use of aluminium also reduced the weight of the housing. The perforations also allowed for mitigation of more wind load compared to a full wall, which was also of utmost importance from the point of view of the load capacity of the existing structure of the ramp. At the same time, the housing of the false wall overlaps the wall of the existing building and masks the window openings of the 
garage. In this case, the aim of the perforations was to allow natural light into the interior of the building. The completed garage and ramp revitalization can be seen in Fig. 4 (compare to Fig. 1d).

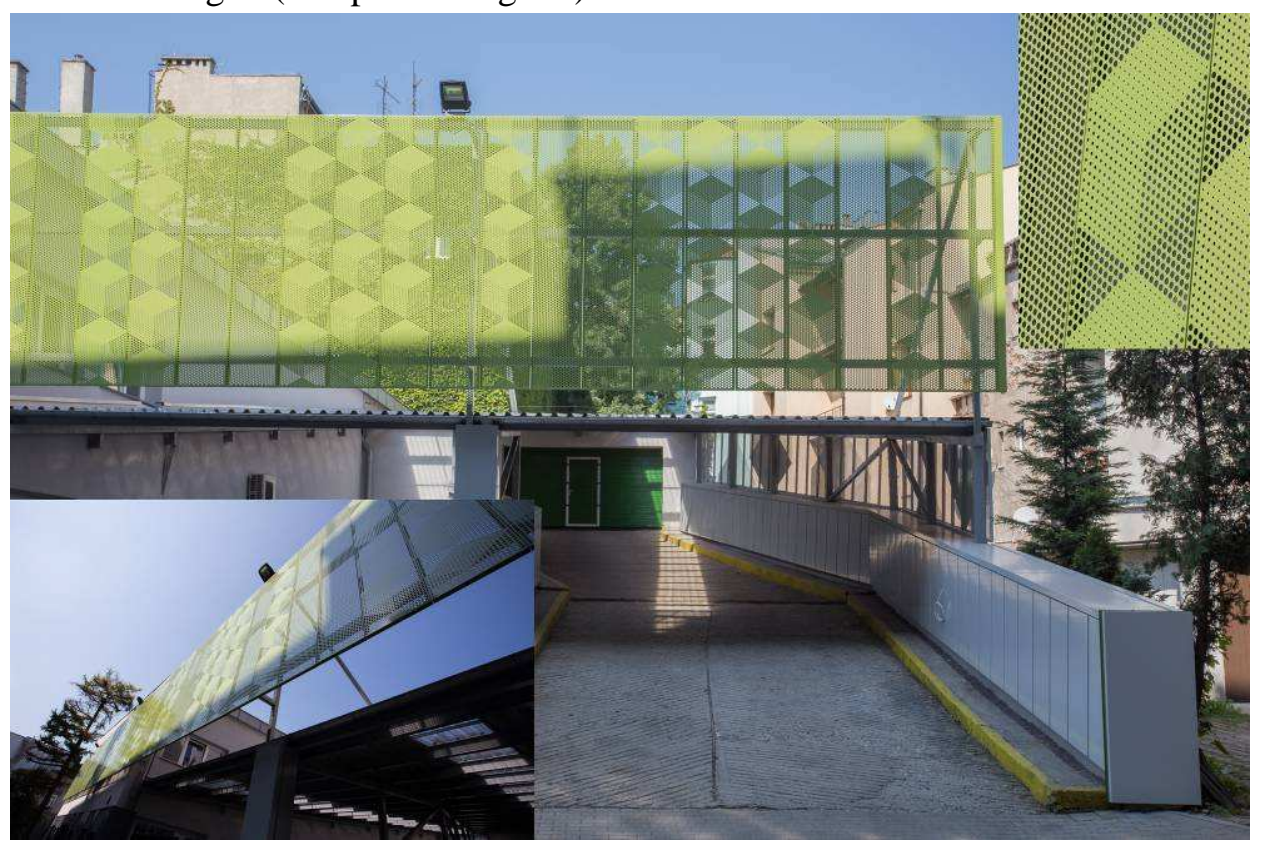

Fig. 4. Garage and ramp façade after revitalization

\section{CONCLUSIONS}

The paper presented selected issues in the revitalization of the façades of an office building and a two-storey garage with access ramps, using full, lightweight and perforated metal cladding.

Light-weight, corrosion-resistant, perforated metals (including the availability of expanded metal mesh) and easy shaping, as well as a virtually unlimited range of colours in powder coating technology make aluminium an excellent material for use in revitalising building façades. Shaped aluminium can give an attractive appearance to boring-looking buildings, even if their location is part of historic or protected urban fabric.

\section{REFERENCES}

1. Aprobata Techniczna ITB AT-15-4058/2010 Aluminiowe ptyty kompozytowe ALUCOBOND A2, ALUCOBOND B2 I ALUCOBOND PLUS, Warszawa, ITB, 2010. 
2. Beiersdorf Z.: Architekt Teodor M. Talowski. Charakterystyka twórczości, Sztuka 2 połowy XIX wieku, redaktor T. Hrankowska Warszawa, PWN 1973, 199-214.

3. ETA-12/0502 Europejska Aprobata Techniczna EJOT Łącznik do betonu komórkowego SDP-S-10G i EJOT SDP-KB-10G

4. PN-68/B-10024 Roboty murowe - Mury z drobnowymiarowych elementów $z$ autoklawizowanego betonu komórkowego - Wymagania i badania przy odbiorze, PKN 1968.

5. Rozporządzenie Ministra Transportu, Budownictwa i Gospodarki Morskiej z dnia 5 lipca 2013 r. zmieniające rozporządzenie w sprawie warunków technicznych, jakim powinny odpowiadać budynki i ich usytuowanie.

\section{REWITALIZACJA ZABUDOWAŃ Z LAT 70. XX WIEKU W OBRĘBIE STAREGO MIASTA W KRAKOWIE}

\section{Streszczenie}

$\mathrm{W}$ artykule przedstawiono wybrane zagadnienia związane $\mathrm{z}$ rewitalizacją fasad budynków zlokalizowanych w obrębie zabytkowej zabudowy miejskiej. Przedmiotem rewitalizacji były fasady budynku biurowego oraz garażu wielopoziomowego wybudowanych w latach 70. XX wieku w obrębie dzielnicy administracyjnej Stare Miasto w Krakowie. Przedstawiono kryteria, którymi kierowano się przy wyborze technologii oraz zastosowanych rozwiązań technicznych. Przedstawiono problemy związane $\mathrm{z}$ realizacją nowych fasad aluminiowych na ścianach, które odznaczają się bardzo dużymi niedokładnościami wykonania, znacznie przekraczającymi wartości normowych tolerancji.

Zarówno w przypadku budynku biurowego, jak i garażu wielopoziomowego zastosowano lekkie okładziny aluminiowe. Niska waga, odporność na korozję, możliwości w zakresie perforowania (w tym dostępność siatek cięto-ciągnionych) oraz formowania kształtów a także praktycznie nieograniczona paleta barw dostępna $\mathrm{w}$ technologii lakierowania proszkowego czyni $\mathrm{z}$ aluminium doskonały materiał do stosowania przy rewitalizacji fasad budynków. Świadomie użyte i ukształtowane aluminium pozwala nieciekawej bryle budynku nadać atrakcyjny wygląd, nawet w przypadku realizacji sąsiadujących bezpośrednio z budynkami zabytkowymi objętymi ochroną konserwatora zabytków.

Słowa kluczowe: budynek biurowy, rewitalizacja, aluminium, perforacja, elewacja wentylowana, siatka cięto-ciagniona

Editor received the manuscript: $25.03 .2015 \mathrm{r}$. 
PUSTA 